In Contemporary Justice Review Issues in Criminal, Social, and Restorative Justice 2017 GCJR-2016-0037.R1

\title{
Immature offenders. A critical history of the representations of the offender in restorative justice
}

\section{Giuseppe Maglione ${ }^{1}$}

Edinburgh Napier University, UK

\begin{abstract}
This paper reconstructs and discuss how the 'offender' is represented within policy documents, legal statutes and scholarly literature on restorative justice, published and circulated in England and Wales over the last thirty years. The research first outlines the most wide-ranging and recurrent images and implicit assumptions of the offender in restorative justice. A set of specific offender's features will be singled out, and the 'ideal offender' of restorative justice will be profiled. The final step of this work consists of mapping out the cultural context within which this ideal has emerged, in a historical perspective. The overall goal is to shed light on some taken-for-granted images surrounding the offender in restorative justice, and on the cultural context within which they have developed. In this way, it is possible to contribute toward the critical reassessment of restorative justice whilst considering implications beyond the British context.
\end{abstract}

\section{Keywords}

Restorative justice, offender, Michel Foucault, archaeology, "conventional” criminal justice

\section{Introduction}

Labels such as 'victim' and 'offender' are neither morally neutral, nor epistemically objective or socially unproblematic (Christie, 1986). On the contrary, they rest on tacit world-views, they are loaded with taken-for-granted values and cultural stereotypes, and project onto people specific features, interests, needs and goals, with powerful effects (Van Dijk, 2009). Recently, a number of critical studies on the tacit assumptions surrounding the 'victim' in restorative justice (RJ) have been published (Bolivar, 2010; Cunneen, 2010; Green, 2007; Maglione, 2016; Pemberton et al., 2007; Van Dijk, 2009). Yet, similar reflections that tackle with ideas of the 'offender' are not available to date (perhaps with the only partial exception of Christie, 2013). What does 'offender' mean in

\footnotetext{
${ }^{1}$ I carried out the research for this paper at the Institute of Criminology, University of Cambridge. I wish to thank the library staff for their support as well as Kirsty Boutle for her invaluable help.
} 
RJ? Which implicit images are associated with this label? Are there any taken-for-granted notions of offender which unwittingly guide RJ scholars' and policymakers' work?

This work aims to explore the images of the offender which underlie policy documents, laws and scholarly literature on RJ, produced between 1980 and 2015 in England and Wales ${ }^{2}$. Through an approach informed by foucauldian archaeology (Foucault, 1970, 1972), the paper begins with a reconstruction of the 'authoritative discourses' on the offender within RJ. This will result in the identification of a range of recurrent offender's features, which will be pieced together into an 'ideal model' (Christie, 1986). The next step contextualises this 'ideal offender', examining the cultural background within which it emerges; then, to finalise, the paper offers some implications and conclusive reflections. Overall, the purpose of this work is to critically reflect on the present of RJ, stimulating a careful analysis of some of its underlying assumptions (e.g. the offender's identity). Along these lines, it is also possible to draw implications for RJ beyond the British borders.

There are four main limitations to the research (Maglione, 2017a, 2017b). Firstly, the following analyses apply only to RJ in (both adult and juvenile) criminal justice settings and practiced by conferencing and victim-offender mediation ${ }^{3}$. Secondly, this work is mainly a theoretical elaboration on legal and policy material and as such tends to be abstract and over-generalising. However, my primary goal is to reconstruct patterns across the representations of the offender in RJ (Garland, 2001: viii). In this perspective, abstraction and generalisation are useful (and even necessary) tools. Thirdly, this work aims to refine and apply certain analytical and conceptual devices (i.e. archaeology and 'ideal offender'), fostering a new strand of research in RJ. This will involve a degree of simplification, hopefully compensated by the productivity, provocation and critical edge of the approach elaborated (Foucault, 1996; Garland, 2001; Pavlich, 2005). Lastly, the inferences from legal/policy data (i.e. to draw the 'ideal offender' from legal statutes and policy documents whilst considering the relevant scholarly literature) are always underdetermined and theory-laden, i.e. many (and possibly incompatible) readings of the same data are possible as well as driven by theoretical views. My interpretations are led by the intention of pointing out a lack in the $\mathrm{RJ}$ literature and a direction for further critical

\footnotetext{
${ }^{2}$ The wide timespan considered could suggest that the images of the offender in RJ may have changed over time. However, it should be clarified that the majority of documents analysed here have been published between 2000 and 2015. In this more limited time frame no significant changes can be identified while continuity seems predominant. The small amount of documents between 1980-2000 does not allow for an analysis of changes over time of the representations of the offender.

${ }^{3}$ In England and Wales the vocabulary of victim-offender mediation arose independently from the RJ. These two vocabularies converged during the late 1980', whereby victim-offender mediation came to be conceptually linked as a specific practice to the RJ theory, also thanks to the reception of Howard Zehr's work (Wright and Galaway, 1989; Marshall, 1996).
} 
research, offering an analytical approach (largely based on Michel Foucault and Nils Christie's works) which aims to raise critical questions whilst consider their implications rather than providing answers.

\section{Methodological remarks}

From a methodological viewpoint, this work is a discursive analysis which combines insights from Nils Christie and Michel Foucault. In the late 1980s Nils Christie identified the key characteristics of the 'ideal victim' (1986) in the media and policy: completely innocent, physically and socioeconomically vulnerable, unrelated to the offender (Christie, 1986: 18). The 'ideal offender' was conversely described as unambiguously big and bad, blameworthy and not related to the victim.

The 'ideal offender' (exactly like the 'ideal victim') is a methodological tool; it aims to simplify and generalise a disparate range of tacit assumptions which underpin the representations of the offender in law, policy and academic literature on RJ (van Wijk, 2013). The 'ideal offender' is inserted within an approach (archaeology) inspired by the work of Michel Foucault $(1970,1972)$. This approach consists of a historical inquiry into the production of discourse in terms of the conditions for its possibility (Foucault, 1970: 168; Garland, 2013: 44). It is epistemologically constructivist and ontologically nominalistic, insofar as it aims to analyse how specific discourses, emerging from historical contingencies, shape social reality and influence people's life (Veyne, 2010: 54). The main advantage of this perspective is that it enables a delimitation of research objects (i.e. discourses on the offender in RJ) by making their historical context intelligible whilst questioning their taken-for-granted naturalness (Howarth, 2002: 128). The first step of this enquiry is to draw the 'archive' (Foucault, 1972: 145) i.e. to reconstruct the 'authoritative discourses' on the offender within RJ (Maglione, 2013). Here 'discourse' refers to an analytical concept 'that the researcher projects onto the reality in order to create a framework for the study' (Jørgensen and Phillips, 2002: 143). To think in terms of 'discourses' helps to reduce the complexity of a fluid, extensive and growing field that is RJ, by identifying a limited set of wide-ranging and deep-rooted perspectives, views and understandings on the offender across laws, policy documents and scholarly literature. The paper will consider the range of relevant legal statutes and policy documents produced between 1980 and 2015 in England and Wales explicitly addressing RJ as a criminal/penal option. The second set of material consists of the scholarly literature which underpins those legal/policy regulations ${ }^{4}$. It is here maintained that the tangle of legal/policy documents which supposedly challenge the "conventional" criminal justice, underpinned by foundational texts on RJ, define the normative backdrop

\footnotetext{
4 The paper also includes an examination of the North American research on RJ as well as of EU and UN policy/legal regulations, due to their well documented influence on the UK research (Marshall, 1996: 23; Marshall and Merry, 1990: 7; Newburn, 1995: 232) and legislation.
} 
of $\mathrm{RJ}$ in the geographical and historical context under analysis. Clearly, this ensemble does not exhaust the entire universe of RJ which includes also how practitioners and other stakeholders interpret and negotiate the meaning of the 'authoritative discourses'. This makes this work (deliberately) incomplete, an initial sketch of a more complex investigation which is yet to come.

Once the archive has been drawn, it is possible to contextualise the recurrent offender's representations (organised in an 'ideal offender'). Methodologically, this analysis entails the detection of the contextual conditions - that is, conditions of possibility (Foucault, 1970: 168) - which have contributed to create the 'authority' of that ideal, penetrating policy, laws and scholarship. Again, the conditions of possibility are analytical tools meant to order conceptually the cultural milieu within which the 'ideal offender' has risen. They do not address the power relations which in a foucauldian framework would also play a crucial role in facilitating the rise of the 'ideal offender' (and of RJ in general) (Foucault, 1984: 387). For reasons of space, an investigation of these two dimensions cannot be carried out in this paper. However, this will likely benefit from the historicalcritical delimitation of research objects enabled by this preliminary archaeological work (Dreyfus and Rabinow, 1983: XXVII; Foucault, 1986: 53).

\section{'Authoritative discourses' on the offender in restorative justice}

It is possible to identify at least five discourses around the offender in RJ, within the relevant context: 1) genuine accountability; 2) repairing the harm; 3) avoiding reoffending; 4) reintegrating into the community and 5) safeguarding offenders.

The discourse on the offender's genuine accountability in RJ revolves around the idea that the criminal offence is both an act against the normative moral/legal order (i.e. a wrong) and against the material victim (i.e. a harm) (Duff, 1992: 52; Johnstone, 2011: 118; Zehr, 2002: 59). From this "double-edge" offence arises both the personal duty to right the wrong and the moral obligation to repair the harm (Justice for All 2002: 7.33; HO Strategic plan 2008: 100). RJ seeks to hold offenders accountable and to enable them to face the impact of the crime on others (Transforming Rehabilitation 2013: 4.10). This idea of accountability is fundamentally linked to a certain concept of 'taking responsibility' (Miers et al., 2001; Zehr, 2005: 40). Responsibility means that 'offenders have an opportunity to [...] "own" their behavior. They can take direct responsibility for their actions by making amends to the person they 'victimized' (Umbreit et al., 1996: 2). The 'ownership in the outcome' (Zehr, 2005: 42), the idea of individually and proactively "taking" responsibility, is highly characteristic of the RJ field, and conversely one of the main purported differences with respect to "conventional" criminal justice (CPS RJ legal guidance: 1; The way ahead, 2001: 17). This form of 'meaningful' (UN Basic principles RJ 2002: preamble) or 'active responsibility' (Marshall, 1999: 6) is mobilised by the typical means of meeting the victim (Crime and Courts Act 2013: sch. 16.12) and possibly the community, as long as the offender has acknowledged the 'basic facts' of the case 
(Breaking the Cycle 2010: 22; RJC best practices 2011: 4; RJ strategy 2003: 5.7; Victims' Code: 7.5). Responsibility refers to something personal (Breaking the Cycle 2010: 22), which should genuinely originate from the full awareness of the crime's human costs, intended as a violation of people's needs, as well as of moral and legal rules (Zehr, 2005). The underlying assumption is that the offender has an impeded sense of moral obligation toward the other crime stakeholders. This lack will be elaborated within the RJ process, by focussing on the crime's impact (Offender Rehabilitation Act 2014: 15.3.8b). Finally, it should be remarked that this conceptualisation of accountability/responsibility is not incompatible with a 'proper punishment' (RJ action plan 2012: 1) or censure, as long as this is 'constructive', i.e. it does not aim to deliberately inflict pain (Daly, 1999: 3; Duff, 1992: 53; Dignan, 2003: 149; Wright, 1991: 15).

Repairing the harm is a fundamental discourse in RJ laws (Crime and Disorder Act 1998: 67), policy documents (Justice for All, 2002: 177; No more excuses 1997: 4.13; RJ strategy 2003: 1.1) and academic literature (Johnstone, 2011: 1; Marshall, 1999: 7; Zehr, 2005: 186). As Zehr emblematically states (2002: 37) 'Restorative justice is a process to involve, to the extent possible, those who have a stake in a specific offense and to collectively identify and address harms, needs, and obligations, in order to heal and put things as right as possible'. One of the main features of RJ is the focus on the harm caused by the offender to the victim and to the larger community. The harm (and therefore the reparation) is routinely conceptualised as either material or symbolic (Retzinger and Scheff, 1996; Sharpe, 2007: 25). Material harms include physical damages to the direct and/or indirect victim. Symbolic harms refer to the breach of trust or more broadly of the interpersonal relationship between parties, by creating a sense of fear and lack of safety (RJ strategy 2003: 1.1). It also includes the breach of the tacit social pact which holds communities together. Different types of harm require different types of reparation. Reparation stricto sensu (i.e. the physical 'fixing' of what has been damaged or broken) compensation and restitution (Christie, 1977; Barnett, 1977; Eglash, 1977) are the main forms of material reparations (UN declaration victims 1985) jointly decided by both parties. Apology or community work (e.g. graffiti removal) are considered typical symbolic reparations, since they supposedly allow to "mend" the relational bond between parties damaged by the crime (Braithwaite, 2000: 115). Furthermore, the active participation in the RJ process, the expression of remorse or atonement (RJ strategy 2003), listening and responding to the victim, are all activities integral to symbolic harm repair. RJ distances itself from "conventional" criminal justice and namely penal retribution, because the latter 'asserts that crime harms the state, and that the state should react by punishing the offender' (Graef, 2000: 22) while RJ focuses on the harm caused or revealed by criminal acts along with healing victims and reintegrating offenders (Johnstone, 2011: 112; Wright, 2011) and is therefore opposed to 'negative justice based on retaliation and retribution' (Harding, 1982: 13). Even if conceptually distinguished, material and symbolic repair are often described as functionally linked (Johnstone, 2011: 
97). Without the symbolic repair, in fact, it may be difficult to achieve agreement about material reparation (Daly, 1999: 15; Retzinger and Scheff, 1996). The settlement (i.e. victim acceptance of the offender's harm repair) rests on the visible repentance showed by the offender within the regulatory framework of the RJ process. This is also encapsulated by the claim that (material) reparation in RJ is a catalyst for offender's reform and rehabilitation (No more excuses 1997: 4.13).

RJ processes are not only meant to fulfil victims' needs and to enable reparation but also to deter the offender from committing future crimes (Breaking the cycle 2010: 30; Facing Up To Offending 2012: 4). More emphatically, it is possible to claim that RJ works only when there is a measurable impact on reoffending (Shapland et al., 2008: i; Marshall, 1999: 6). The implicit idea is that RJ processes can tackle underlying offending causes, and therefore reduce the likelihood to reoffend (Johnstone, 2011: 3). One of the most distinctive routes for reducing reoffending within $\mathrm{RJ}$ is through the moral psychological process of 'reintegrative shaming', which is characteristic of many RJ processes ${ }^{5}$ (Braithwaite, 1989; Walgrave and Aertsen, 1996). The basic claim here is that the disapproval of the criminal act within a frame of respect for the offender, terminated by rituals of forgiveness or acceptance, prevents reoffending. A certain moral psychology of the offender seems to permeate this discourse. The aim of reintegrative shaming is in fact to make offenders experience trauma from shame which derives from telling the story of the crime and listening to the victim. This trauma is handled (for instance through 'the compass of shame' (IIRP, 2007: 3)) and directed by the practitioners on the criminal act, enabling the offender to maintain a sense of worth and self-respect. This can be achieved by exposing her/him to the emotional views of those whom she/he most cares about (e.g. parents, partners and friends) (Hoyle, Young and Hill, 2002). At this point, once the trauma has been elicited, redirected and fashioned, the symbolic/material reparation can take place. This is also the moment when the offender is 'asked' to commit herself/himself to changing life, which obviously entails to avoid reoffending (Johnstone, 2011: 97). Avoiding reoffending is also said to depend on the meaningful involvement in the decision-making process and on the degree of genuine remorse experienced (RJ strategy 2003: 3.7). Conversely, re-offending seems implicitly linked to a lack of emotional understanding i.e. a mix of reduced empathy toward the victim and shortage of knowledge regarding the material effects of the crime and its aftermath (i.e. the harm). It is this lack which, if not properly "filled", might facilitate re-offending in the future. At the same time, this finally achieved emotional understanding seems to be the main gain that the offender receives from partaking in $\mathrm{RJ}$ processes along with the possible reconciliation

\footnotetext{
${ }^{5} \mathrm{RJ}$ processes based on the theory of reintegrative shaming were introduced in the UK in the mid-1990s by the Thames Valley Police and have since been used by many other UK police forces 'so that in the UK, RJ has come to be identified for many years with Braithwaite's theory of reintegrative shaming and the Wagga model of conferencing' (Johnstone, 2011: 4).
} 
with the victim. This gain is often described as transformative (RJ strategy 2003: 3.2) and even life changing (RJ action plan 2012: 2).

Taking responsibility, repairing the harm and avoiding re-offending are directly linked to the discourse of reintegration into the community (No More Excuses 1997: 9.21; UN Basic principles RJ 2002: 1.3). In RJ, the psychological dynamics elicited and organised within the meeting with the victim as well as the material consequences of these (e.g. repairing the harm) are preliminary steps toward the offender's reintegration back into the community (Marshall, 1999: 6; Zehr, 2002: 38). The very attendance to a RJ encounter represents a symbolic moment of reintegration as re-acceptance of the offender. In this context, reintegration refers to the offender's inclusion into a community-based positive moral order (Van Ness and Strong, 2015: 39) to be achieved (or stimulated) within the RJ meeting, symbolically (the fact of taking part) and psychologically (e.g. reintegrative shaming). We can map out two different forms of restorative reintegration: into the microsocial community (material/psychological repair of damaged social relationship with the victim) and into the macro-social setting (dialogue the family members or parties networks) (McCold, 2004). The restorative reintegration then, entails both the material engagement with the other stakeholders (victim and community) and the symbolic reentry into the moral/legal order.

Finally, the concerns around safeguarding offenders' rights within RJ processes constitute an important discourse across legal/policy regulations (Coe R (99)19: 3.8; Justice for All 2002: 9.37; Criminal Justice Act 2003: 22-23; RJ strategy 2003: Q20-21; UN Basic principles RJ 2002: 13a-c) and scholarly works (Ashworth, 1993, 2002; Von Hirsch, Ashworth and Shearing, 2003). The offender in RJ is also a legal subject entitled to rights, safeguards and protections (Ashworth, 2002: 578). The main legal right consistently recognised to the offender is participation upon free consent (EU Victims' Directive 2012: 2.1d; UN Basic principles RJ 2002: 7). The idea of coercing participation to RJ encounters is not contemplated within laws and policy documents (even though the idea of 'imposing reparation' is an option present within the literature (Duff, 1992; Walgrave, 2003b)). Other safeguards concern the right to consult with a lawyer, to the assistance of a parent or guardian, to be fully informed of their rights (UN Basic principles RJ 2002: 13a-c). This rights-based discourse clearly resonates with the due process which characterises the "conventional" criminal justice and it is usually considered one of the few merits of the 'old paradigm' to be recovered by RJ (Zehr, 2005).

These are only some of the 'authoritative discourses' which compose the legal, policy and academic archive of RJ - the ones more directly related to the offender's identity. At this point, it is possible to combine into an ideal framework the emerging offender's features and then to offer a contextualisation of this resulting ideal model.

\section{Profiling the 'ideal offender'}


In the RJ archive, offenders are routinely portrayed as a homogenous category, characterised by recurrent needs, interests and duties. This actor appears as a "strong" decision-maker who is required to take active responsibility for the wrong/harm caused; she/he is lacking in emotional understanding of the crime's human costs, which can be appreciated only by meeting the victim and the community. This offender seems to be not fully integrated in the community's normative moral/legal order, but she/he is still "one of us", a community member. To sum up the recurrent offender's features in RJ, they are: 1) harmful wrongdoer; 2) powerful; 3) looking for redemption; 4) immature. To these should be added a number of characteristics (i.e. embodiment, exclusivity and undifferentiated nature) which apply also to the other crime stakeholders in RJ (Maglione, 2016, 2017a).

The offender in RJ is consistently represented as both a wrongdoer and a harm-maker. These two features are ontologically linked to each other: the harm caused is a wrong, i.e. a material/psychological injury against the victim/community and a breach of the social pact. This representation looks similar to the one held by the "conventional" criminal justice, even though important differences should be considered. First, "conventional" criminal justice (as depicted within RJ law, policy and scholarship) prioritises the wrong over the harm, as the target of adjudication and punishment, while in RJ the offender is represented first and foremost (but not solely) as a harm-maker, materially and symbolically. The offender damages, breaks, and produces losses. At the same time, she/he is also a wrongdoer, insofar as the damage is also a wrong, an instance of a breach of the social pact. This specific offender's conceptualisation in RJ, makes the compatibility between harm-repairing (focus on the material/symbolic harm) and traditional punishment (focus on the wrong) possible.

A further stereotyped characteristic of the 'ideal offender' is that she/he is powerful. The offender is in a position of personal control, being able to impose unidirectionally and top-down a certain course of action to the victim, who is correlatively passive and compliant. This power defines the victim's possibilities of acting and perhaps feeling. The victim is subjected to the offender's determination, who additionally is never influenced by the victim's actions, avoiding any possibility of shared responsibility. In the archive there seems not to be any reference to a more nuanced interaction between the environment (human, social etc.) and the offender's decision-making process. The crime is a quite straightforward consequence of a choice made by the offender in a situation of lack of emotional understanding of the human consequences of her/his behaviour, or lack of attention toward a harm that is not self-evident. Here sits the assumption that once this "gap" is filled in a safe environment and following an organised pattern, the offender will be enabled to repent, express regret, possibly apologise and compensate, i.e. to repair.

In RJ, the offender is neither deprived nor depraved. She/he appears instead as immature, from an emotional viewpoint, as well as not completely integrated within the fabric of the normative community order. The offender is often portrayed as a 'wayward child' 
(Wright, 1996), whose actions involve both free will and psychological determinism (Eglash, 1977: 92). Her/His emotions, moods, feelings are like "raw material" to be fashioned in order to discipline the otherwise overwhelming tendencies toward fulfilling her/his needs without considering the consequences. The 'game of blame and pain' (Zehr, 2005: 74) for this type of offender does not work. This is the offender exemplified by the originary case of Elmira, Ontario, in 1974, whereby two youngsters vandalised the quiet neighbourhood calling for a different (restorative) way of doing justice (Peachey, 1989). This model of offender seems ingrained in the collective imaginary of what RJ is and who/what it deals with ${ }^{6}$. Also relevant here, is the image of the police officer giving a street-level restorative caution to the youngster who is not completely aware of what she/he is doing. To this offender, RJ aims at offering a low-threshold form of responsibilisation in a naturalistic context (Crawford and Newburn, 2003). This picture of the 'ideal offender' of RJ is nuanced by the claim, advanced in some of the scholarly literature, of the offender using 'neutralisation techniques' in order to limit shame and guilt associated to the crime (Johnstone, 2011: 81; Wright, 1999: 56; Zehr, 2005: 40).

Another feature of the RJ offender is that she/he is engaged in 'earning redemption' (Bazemore, 1998), through symbolic and/or material actions. This moral(istic) process refers to the active work toward social reintegration and moral maturation in order to fulfil the victim and community's needs. This means that the offender strives for a repairing of the harm and a rectifying of the wrong in order to earn the full community's membership back and the reconciliation with the victim. The victim (along with the community) holds the key to make the repentance, regret and apology or any other form of reparation, "redemptive". Within the RJ encounter the offender is first of all a listener of the victim's story which has to be told and carefully listened to. The offender will be required to answer the victim's questions. The decision whether the encounter has been meaningful, genuine, and/or reintegrative lies mainly with the victim, who decides whether to agree to the action plan and to accept symbolic reparation. The possibility that the offender may reject the victim's story or the reparation, is not considered. This seems a direct consequence of the RJ encounter being not a dispute resolution meeting but a unique penal option which rests on the offender's preliminary admission of responsibility. The idea of 'earning redemption' also highlights how in RJ the offender is enmeshed with the community's bonds and ties that once broken determine the offender's temporary "fall" as a member, now perceived as a failure to be amended by the same offender, therefore creating the need for self-redemption. This is because the offender is considered to share the same moral milieu as the victim. She/he is imbricated in the thick fabric of mores and habits, normative expectations and formal and informal sanctions, which characterise a nostalgic representation of a fusional community.

\footnotetext{
${ }^{6}$ In this regard, see the case studies in the policy documents produced by the Home Office or by the RJ Council which often portray juvenile offenders as paradigmatic examples of RJ processes participants.
} 
Finally, there are some further recurrent aspects of the RJ offender, shared with both the 'ideal victim' and the 'ideal community' of RJ (Maglione, 2016, 2017a). The offender in $\mathrm{RJ}$ is often described as a physical body, clearly identifiable, not a social structure or organisation, but a definite individual able to directly harm the victim/community. The idea of offender as a corporation or a State, or any other disembodied entity, is difficult to be drawn from the archive; it seems that RJ is built around a human, flesh-and-blood offender. This is because RJ explicitly uses an embodied language made of metaphors and figures of speech, above all promoting experiences grounded in perceptions of physical proximity and in actions related to enhancing or decreasing physical distance (Meier et al., 2012: 707), none of which have a correspondent in "conventional" criminal justice. The idea of personalising the crime, or the victim-offender meeting, are examples of this embodied language. A further characteristic, is that the offender of $\mathrm{RJ}$ is exclusive, i.e. ontologically separated from the victim. In RJ either one is a victim or an offender, there is no room for (social, personal, cultural) overlaps between those two positions. The idea of a victim/offender, i.e. a subject who is at the same time harmed but also harming, does not seem compatible with the 'ideal offender' of RJ. Perhaps, there is only one implicit commonality between victim and offender in RJ. This is their "belonging" to the same community. Finally, the 'ideal offender' is apparently an undifferentiated subject, that is: ageless, genderless, colourless and classless (Young, 2002: 146). There is not explicit reference to the offenders' socio-demographic background in laws, policy documents and scholarly literature on RJ, seemingly assuming that anyone could occupy this position in a RJ process, in similar ways and with similar effects. The offender in RJ is portrayed as detached from any gender, geopolitical, ethnic, socio-economic condition, somehow like the apparently neutral subject at the heart of the "conventional" criminal justice. However, the features underlying the RJ offender analysed above, seem particularly consistent with a young male offender, a member of "our" community.

To sum up, the 'ideal offender' of RJ exemplifies an immature wrongdoer who harms a discrete victim, and lacks of emotional understanding. The community's ties with the offender are weak, but still exerting forms of control over her/him. This offender is a flesh-and-blood individual who tries to earn redemption by "paying back" the human costs of her/his actions. This representation clearly ignores the possible social, cultural economic constraints of the offender's choice as well as the fluid relations between these two dimensions, emphasising individual agency and conveying images of physical harms. Additionally, the possibility of overlaps or shared responsibility with the victim seem obliterated.

\section{Conditions of possibility}

At this point, it is possible to reconstruct the historical context within which the 'ideal offender' arises, by identifying and combining a range of 'conditions of possibility' (Foucault, 1970: 168). These conditions do not constitute a coherent set of causal factors, 
a general trend or an all-encompassing scenario. They are instead some of the most salient ${ }^{7}$ ingredients of the cultural background within which the 'ideal offender' emerges: by overlapping, competing and conflicting, they have provided scholars, practitioners and policymakers with certain vocabularies, particular ways of making sense of crime and crime responses, producing distinctive needs and interests in context. The 'ideal offender' (and RJ more broadly) is consistent with those vocabularies, appeals to new understandings of crimes, and responds to those needs and interests.

The first condition to be considered is the development in the UK (and in the Englishspeaking world more generally) of an intellectual approach to crime different from both the 'criminologies of self' and of the 'criminologies of the other' (Garland, 2001: 137). These "third way" criminologies (cf. O'Malley, 1996) which develop across the late1980s and 1990s understand crime as an effect of the progressive erosion of micro-moral ties localised in discrete communities (Braithwaite, 1989, 2000, 2002; Braithwaite and Pettit, 1990; Duff, 1992, 2000; Dzur, 2003) to be tackled by promoting social integration and civic participation. The idea of 'community' here consists of a combination between the notion of 'civil society' elaborated by the left and the idea advanced by contemporary civic republicanism of community as an instrument by which to counter liberal individualism (Dzur, 2003). Victims and offenders are thought as entangled in social interdependencies which have a symbolic significance which takes precedence over individual interests (Braithwaite, 1989: 100). The offender, in particular, is conceptualised as breaching the interpersonal trust which ties her/him together with the victim within a shared community. This "third way" knowledge does not propose psychosocial corrections or tough punitive reactions, but moralising and responsibilising interventions into the community (Hoyle and Noguera, 2008) often not led by any professional expertise (in RJ there are volunteering 'practitioners' and not experts). In a broader sense, this discourse describes the offender as autonomous but in need of regulation, self-determined but immature, self-sustaining but only within the community (Shamir, 2008: 7). The offender lacks moral ties and is emotionally immature, but at the same time is required to take responsibility in a context which is community-based and victim-centered. She/he is required to take action, be involved, speak out and listen as a condition for reintegration into the community. Consistently, the response to criminal behaviour is 'positive', i.e. meant to 'induce and manifest that process of repentance, reform, and reparation which will restore the offender's moral standing in the community' (Duff, 1992: 54).

The popularisation of psychological ideas about human resources and group dynamics into an increasing number of social domains (Rose, 1985; Richards, 2005), is also a relevant factor to be taken into account. Overall, this phenomenon, which develops during

\footnotetext{
7 The criterion followed to select these conditions has been the presence of overlapping similarities between the discourses on the offender in RJ and the very discourses which constitute these conditions.
} 
the second half of the XXth century in the Western world, involves 'a plethora of indirect mechanisms that can translate the goals of political, social, and economic authorities into the choices and commitments of individuals' (Rose, 1998: 165). It offers individuals, groups and communities new opportunities to participate actively in various arenas of action 'to resolve the kind of issues hitherto held to be the responsibility of authorized governmental agencies' (Burchell, 1996: 29). From a penal policy perspective, this means emphasis on individual agency, at the expenses of structural constraints, as far as both the "causes" of and responses to crimes are concerned. Crime is a matter of interpersonal conflict to be dealt with by the same conflicting parties; the role of social-structural determinants or macro-relations of power, is neglected if not denied. Offenders are 'encouraged [...] to conduct themselves' (Burchell, 1996: 29), and to become "'experts of themselves", to adopt an education and knowledgeable relation of self-care in respect of their bodies, their minds, their forms of conduct and that of the members of their families' (Rose, 1996: 59)

The feminisation of justice (Daly, 2002; Fergusson and Muncie, 2010: 96; Smart, 1989), i.e. the debate on the absence of a different (female) voice (Heidensohn, 1986; Harris, 1987) or the reproduction and maintenance of gendered power relations, in criminal justice (Daly, 1989), is also part of the landscape within which emergences RJ in general, and the 'ideal offender' in particular. The academic discussions on the contraposition (perhaps sometimes oversimplifying (Daly, 1989)) between a "masculine" (based on rights, fairness, formality and equality) and "feminine" (stressing reformation, cooperation, informality and reparation) ethical reasoning (Gelsthorpe, 2004: 19) have paved the way for re-thinking meanings and effects of the "conventional" criminal justice (namely penal retribution). In this debate, restorative and relational justice, or the concept of reintegrative shaming, have been often conceptualised as more "caring" ways of doing justice. This is because they prioritise care and well-being, by focussing on the crucial nature of interpersonal relationships (Fergusson and Muncie, 2010: 96). The 'ideal offender' (and in a different way also the 'ideal victim') of RJ, resonates with this debate, insofar as is depicted as someone who is an object of concern, to moralise and emotionally educate.

A further underpinning is the emergence during the 1980s in the UK of a number of theories revolving around the idea of 'civilising' criminal justice (Bottoms, 2003: 84). This theoretical tangle contains different but interlinked cultural components, such as the advocacy for restitution, compensation and mediation in criminal matters (Harding, 1982; Wright, 1982; Wright and Galaway, 1989) and the growing interest around the abolitionist stance and its implications for dispute settlement (Bianchi, 1994; Christie, 1977; Hulsman, 1986). In this articulated formation, crimes are thought of as problematic situations or conflicts to be mediated and handled by involving the direct stakeholders. The offender and the victim, through "civilised" and community-based measures, can 
positively manage the human consequences of criminal acts, regaining control over their lives.

The landscape within which RJ emerges appears also characterised by New Labour's endeavour to "break" with conservative law and order policies during the late 1990s, and by the development of knowledges and doctrines coextensive with this supposed break (Muncie, 2004: 279). The focus on (or rather the production of) an idealised community as well as the responsibilisation of 'victims' and 'offenders' in dealing with crimes can be read as expressions of this project (CCJS, 2011: 8). More precisely the focus on youth offenders and anti-social behaviour resonate with the type of offender which shines through legal and policy documents on RJ analysed above. In this perspective, it should be remarked that the first attempts to insert in normative documents the idea of the offender's repair of the harm caused as a consequence of crime, were New Labour's landmark penal policy initiatives, i.e. the Crime and Disorder Act 1998 and the Justice for All white paper 2002.

To conclude, it should be noticed that to overemphasise "new" cultural strands as the underpinnings of the 'ideal offender' (and of RJ in general), might be theoretically and empirically unconsidered. This is because "past" intellectual models, apparently outmoded by the late modern social and political change, seem to survive in the words and deeds of RJ practitioners, advocates and academics. The 'exclusivity' of the 'ideal offender' of RJ, for instance, appears to be conceptually close to a dichotomic view of the legal subject ingrained in the "conventional" criminal justice. Furthermore, the focus on reintegration into the community conceptualised in RJ, still resonates with the correctionalist idea of rehabilitation. In this analysis, it is therefore necessary to pay attention to both new and to old cultural formations (Daly, 2002), avoiding both the blind celebration of the present and the fetishisation of the past.

On the whole, these unrelated discourses compose the pre-existing cultural milieu within which the 'ideal offender' of RJ has slowly emerged. This stereotype develops under specific discursive conditions, being therefore not defined by its internal nature, but by the overlap, intersection and conflict between those cultural constructs (Maglione, 2013). Clearly, other legal, social and political factors have also played a role (e.g. discourse on economic efficiency, victims' movements claims, transformations in the role youth justice etc), but it falls beyond this paper's scope to investigate all of them ${ }^{8}$.

\section{Conclusive remarks}

RJ embraces a specific image of offender: powerful, harmful, striving for redemption, immature as well as embodied, exclusive and apparently undifferentiated. This model is partially overlapping with Christie's original ideal (Christie, 1986: 18-19). The offender in RJ lacks emotional understanding and empathy (but can be healed), her/his decision to

\footnotetext{
${ }^{8}$ For a more thorough analysis of these factors please see Maglione, 2017b.
} 
harm can be turned into a decision to care, her/his immaturity elicits moralisation through shaming within a shared community. The representations underpinning policy/legal documents as well as the relevant academic literature, seem to configure a relatively homogenous individual with recurrent traits of 'youth'. This stereotype is historically rooted in a range of cultural formations which represent some of the most deep-seated scholarly and political underpinnings of RJ in general. The responsibilisation of crime stakeholders within the "third way" criminologies and the New Labour criminal policy, the debates on the feminisation of criminal justice, the popularisation of psy-discourses as well as the attempts to civilise criminal justice (and the relicts of the retributivist and correctional penal discourses) compose the cultural backdrop against which the ideal offender' of RJ arises, makes sense and becomes appealing.

A number of practical implications could be drawn from this study. The 'ideal offender' could be used as a starting point by RJ practitioners, possibly influencing their expectations toward participants. In turn, by guiding practitioners' work, it could also impact on participants' experiences, in terms of exerting pressure toward adjusting to the ideal (which might in turn elicit resistance). Further, a possible implication is relative to the scope of this 'ideal offender'. It is arguable that this model does not properly fit with several types of offenders such as corporations, States, white-collars, but also vulnerable offenders and offenders who do not share any sense of community with the victim because of being cultural outcasts. Even less so, this model seems to apply to individuals whose crimes are deliberate (political) challenges to the establishment. As a consequence, problems in terms of proposing and practicing RJ for these categories of offenders would be likely to arise.

The main goal of this paper is to draw out a framework able to challenge the unproblematic offender's position in RJ. It is hoped that the historical delineation of the 'ideal offender' enabled by the archaeological investigation carried out here, will provoke further theoretical and empirical research on this neglected subject. 


\section{References}

Ashworth A (2002) Responsibilities, rights and restorative justice. British Journal of Criminology 42(3): 578-595.

Ashworth A (1993) Some doubts about restorative justice. Criminal Law Forum 4(2): 277-299

Barnett R (1977) Restitution: A New Paradigm of Criminal Justice. Ethics 87(4): 279_ 301

Bazemore G (1998) Restorative Justice and Earned Redemption: Communities, Victims and Offender Reintegration. American Behavioral Scientist 41(6): 768-813.

Bianchi H (1994) Justice as sanctuary : toward a new system of crime control. Bloomington: Indiana University Press.

Bolivar D (2010) Conceptualizing Victims' 'Restoration' in Restorative Justice. International Review of Victimology 17(3): 237-265.

Bottoms AE (2003) Some sociological reflections on Restorative Justice. In: von Hirsch A et al. (eds) Restorative justice and criminal justice: Competing or reconcilable paradigms? Oxford: Hart, pp. 79-114.

Braithwaite J (1989) Crime, Shame and Reintegration. Cambridge: University of Cambridge Press.

Braithwaite J (2000) Repentance rituals and restorative justice. Journal of political philosophy 8(1): 115-131.

Braithwaite J (2002) Restorative justice and responsive regulation. New York: Oxford University Press.

Braithwaite J and Pettit P (1990) Not Just Deserts: A Republican Theory of Justice. New York: Oxford University Press.

Burchell G (1996) Liberal government and techniques of the self. In: Barry A, Osborne T and Rose N (eds) Foucault and political reason. London: UCL Press, pp. 19-36

Centre for Crime and Justice Studies (CCJS) (2011) Lessons for the Coalition: an end of term report on New Labour and criminal justice. Available at https://www.crimeandjustice.org.uk/sites/crimeandjustice.org.uk/files/end\%20of\%20ter m\%20report.pdf (accessed 12.01.2017)

Christie N (1977) Conflicts as property. British Journal of Criminology 17(1): 1-15. Christie N (1986) 'The ideal victim'. In: Fattah E (ed) From Crime Policy to Victim Policy. Reorienting the Justice System. Basingstoke: Macmillan, pp. 17-30.

Christie N (2013) Words on Words. Restorative Justice: An International Journal 1(1): $15-19$.

Crawford A and Newburn $\mathrm{T}$ (2003) Youth Offending and Restorative Justice: Implementing reform in youth justice. Cullompton: Willan.

Cunneen C (2010) The limitations of restorative justice. In: Cunneen C and Hoyle C (eds)

Debating restorative justice. Oxford: Hart, pp. 101-189. 
Daly K (1989) Criminal justice ideologies and practices in different voices: Some feminist questions about justice. International Journal of the Sociology of Law 17(1): 118

Daly K (1999) Revisiting the Relationship between Retributive and Restorative Justice. Available at: http://www98.griffith.edu.au/dspace/bitstream/handle/10072/1051/?sequence $=1$

Daly K (2002) Restorative Justice. The real story. Punishment \& Society 4(1): 55-79. Davis G (1992) Making Amends: Mediation and Reparation in Criminal Justice. London: Routledge.

Dignan J (2003) Towards a systemic model of restorative justice. In: von Hirsch A et al. (eds) Restorative justice and criminal justice: Competing or reconcilable paradigms? Oxford: Hart, pp. 135-156.

Dreyfus HL and Rabinow P (1983) Michel Foucault: Beyond Structuralism and Hermeneutics, $2^{\text {nd }}$ ed. Chicago: University of Chicago Press.

Duff RA (1992) Alternatives to punishment - or alternative punishments? In: Cragg W (ed) Retributivism and Its Critics. Stuttgart: Steiner, pp. 44-68.

Duff RA (2000) Punishment, Communication and Community. New York: Oxford University Press.

Dzur AW (2003) Civic Implications of Restorative Justice Theory: Citizen Participation and Criminal Justice Policy. Policy Sciences 36(3): 279-306

Eglash A (1977) Beyond restitution: Creative restitution. In: Hudson J and Galaway B (eds) Restitution in criminal justice. Lexington: Heath, pp. 91-100.

Fergusson R and Muncie J (2010) Conflict resolution, restoration and informal justice. In: Drake D, Muncie J and Westmarland L (eds) Criminal Justice: Local and Global. Cullompton: Willan, pp. 71-105. Foucault M (1970) The Order of Things: An Archaeology of the Human Sciences. New York: Pantheon Books.

Foucault M (1972) The archaeology of knowledge. New York: Pantheon Books.

Foucault M (1984) Polemics, Politics and Problematizations. An interview with Michel Foucault. In: Rabinow P (ed) The Foucault Reader. London: Penguin Books, pp. 381390.

Foucault M (1986) The History of Sexuality, Vol. III: The Care of the Self. New York: Pantheon Books.

Foucault M (1996) What is Critique? In: Lotringer S (ed) Foucault Live: Collected Interviews, 1961-1984. New York: Semiotext(e), pp. 41-81.

Garland D (2001) The Culture of Control: Crime and Social Order in Contemporary Society. Oxford: Oxford University Press

Garland D (2013) What does it mean to write a "History of the present"? Foucault, genealogy and the history of criminology. Quaderni fiorentini per la storia del pensiero giuridico moderno 42: 43-57. 
Gelsthorpe L (2004) Back to Basics in Crime Control: Weaving in Women. A gendered reading of David Garland's analysis of The Culture of Control. Available at: http://www.crim.cam.ac.uk/people/academic_research/loraine_gelsthorpe/lrg10-1.pdf Graef R (2000) Why Restorative Justice? Repairing the harm caused by crime. London: Calouste Gulbenkian Foundation.

Green S (2007) Restorative Justice and the Victims' Movement. In: Johnstone G and Van Ness D (eds) A Handbook of Restorative Justice. Cullompton: Willan, pp. 171-191.

Harding J (1982) Victims and Offenders. London: Bedford Square Press.

Harris MK (1987) Moving into the new millennium: Toward a feminist vision of justice. The Prison Journal 67(2): 27-38.

Heidensohn F (1986) Models of Justice: Portia or Persephone? Some Thoughts on Equality, Fairness and Gender in the Field of Criminal Justice. International Journal of the Sociology of Law 14(3-4): 287-298.

Hoyle C, Young R and Hill R (2002) An evaluation of the implementation and effectiveness of an initiative in restorative cautioning. Available at: https://www.jrf.org.uk/file/36675/download?token=C9ac 8gX

Hoyle C and Noguera S (2008) Supporting young offenders through restorative justice: Parents as (In)appropriate adults. British Journal of Community Justice 6(3): 67-85.

Howarth D (2002) An Archaeology of Political Discourse? Evaluating Michel Foucault's Explanation and Critique of Ideology. Political Studies 50(1): 117-135.

Hulsman L (1986) Critical Criminology and the Concept of Crime. Contemporary Crises 10(3-4): 63-80.

IIRP (2007) Introduction to Restorative Practices. Available at:http://www.swansea.gov.uk/media/6566/IIRP---Introduction-to-Restorative-

Practices/pdf/Introduction_to_Restorative_Practices_IIRP.pdf.

Johnstone G (2011) Restorative Justice: Ideas, values, debates, $2^{\text {nd }}$ ed. London and New York: Routledge.

Jørgensen M and Phillips L (2002) Discourse Analysis as Theory and Method. London: Sage.

Liebmann M (2007) Restorative Justice: How it Works. London and Philadelphia: Jessica Kingsley Publishers.

Maglione G (2013) Problematizing restorative justice: A Foucauldian perspective. In: Gavrielides T and Artinopoulou V (eds) Reconstructing restorative justice. Philosophy, values, norms \& methods reconsidered. Farnham: Ashgate, pp. 67-90.

Maglione G (2016) Embodied Victims. An archaeology of the 'ideal victim' of restorative justice. Criminology \& Criminal Justice DOI: 10.1177/1748895816677172

Maglione G (2017a) Communities at Large: An Archaeological Analysis of the 'Community' Within Restorative Justice Policy and Laws. Critical Criminology DOI:10.1007/s10612-017-9349-8 
Maglione G (2017b) Imaging victims, offenders and communities. An investigation into the representations of the crime stakeholders within restorative justice and their cultural context. International Journal of Law, Crime and Justice DOI:10.1016/j.ijlcj.2017.02.004

Marshall T (1996) The evolution of restorative justice in Britain. European Journal on Criminal Policy and Research 4(4): 21-43.

Marshall $\mathrm{T}$ (1999) Restorative Justice: An Overview. Available at: http://www.homeoffice.gov.uk/rds/pdfs/occ-resjus.pdf

Marshall T and Merry S (1990) Crime and accountability: victim/offender mediation in practice. London: Home Office.

McCold P (2004) What is the Role of Community in Restorative Justice Theory and Practice? In: Zehr H and Toews B (eds) Critical Issues in Restorative Justice. Monsey, New York and Cullompton, Devon, UK: Criminal Justice Press and Willan Publishing, pp. 155-171.

Meier BP et al. (2012) Embodiment in social psychology. Topics in Cognitive Science 4(4): 705-716.

Miers D et al. (2001) An exploratory evaluation of restorative justice schemes. London: Home Office.

Muncie J (2004) Youth and Crime. London: Sage

Newburn T (1995) Crime and criminal justice policy. London: Longman.

O'Malley P (1996) Post-Social Criminologies Some Implications of Current Political Trends for Criminological Theory and Practice. Current Issues in Criminal Justice 8(1): 26-39.

Pavlich G (2005) Governing paradoxes of restorative justice. London: Glasshouse Press. Peachey DE (1989) Kitchener Experiment. In: Wright M and Galaway B (eds) Mediation and Criminal Justice: Victims, Offenders and Community. London: Sage, pp. 14-26

Pemberton A, Winkel F-W and Groenhuijsen MS (2007) Taking Victims Seriously in Restorative Justice. International Perspectives in Victimology 3(1): 4-14.

Retzinger S and Scheff T (1996) Strategy for Community Conferences: Emotions and Social Bonds. In: Galaway B and Hudson J (eds) Restorative Justice: International Perspectives. Monsey: Criminal Justice Press, pp. 315-336.

Richards K (2005) Unlikely friends? Oprah Winfrey and restorative justice. Australian and New Zealand Journal of Criminology 38(3): 381-399.

Rose N (1985) The Psychological Complex: Psychology, Politics and Society in England, 1869-1939. London: Routledge.

Rose N (1996) Governing "advanced" liberal democracies. In: Barry A, Osborne T and Rose N (eds) Foucault and political reason. London: UCL Press, pp. 37-64.

Rose N (1998) Inventing Our Selves: Psychology, Power, and Personhood. Cambridge: Cambridge University Press. 
Shamir R (2008) The age of responsibilisation: on market-embedded morality. Economy and Society, 37(1): 1-19.

Shapland J et al. (2008) Does restorative justice affect reconviction? The fourth report from the evaluation of three schemes. Available at: https://www.restorativejustice.org.uk/sites/default/files/resources/files/Does\%20restorat ive\%20justice\%20affect\%20reconviction.pdf

Sharpe S (2007) The idea of reparation. In: Johnstone G and Van Ness D (eds) Handbook of Restorative Justice. Cullompton: Willan, pp. 24-40. Smart C (1989) Feminism and the power of law. London: Routledge.

Strang H (2003) Justice for victims of young offenders: the centrality of emotional harm and restoration. In: Johnstone G (ed) A Restorative Justice Reader: Texts, Sources and Context. Cullompton: Willan, pp. 286-293.

Umbreit M et al. (1996) Mediation of Criminal Conflict in England: An Assessment of Services in Coventry and Leeds. Available at: http://www.cehd.umn.edu/ssw/rjp/resources/Research/Mediating_Criminal_Conflict_En gland.pdf

Van Dijk J (2009) Free the Victim: A Critique of the Western Conception of Victimhood. International Review of Victimology 16(1): 1-33.

Van Ness D and Strong HK (2015) Restoring justice, $5^{\text {th }}$ ed. Cincinnati: Anderson.

Van Wijk J (2013) Who is the 'little old lady' of international crimes? Nils Christie's concept of the ideal victim reinterpreted. International Review of Victimology 19(2): 159179.

Veyne P (2010) Foucault. Cambridge: Polity Press

Von Hirsch A, Ashworth A and Shearing C (2003) Specifying Aims and Limits for Restorative Justice: A 'Making Amends' Model? In: von Hirsch A et al. (eds) Restorative justice and criminal justice: Competing or reconcilable paradigms? Oxford: Hart, pp. 21-42.

Walgrave L (ed) (2003a) Repositioning Restorative Justice. Cullompton: Willan.

Walgrave L (2003b) Imposing Restoration Instead of Inflicting Pain. In: von Hirsch A et al. (eds) Restorative justice and criminal justice: Competing or reconcilable paradigms? Oxford: Hart, pp. 61-78

Walgrave L and Aertsen I (1996) Reintegrative shaming and restorative justice: interchangeable, complementary or different?, European Journal on Criminal Policy and Research 4(4): 67-85.

Wright M (1982) Making Good: Prisons, Punishment, and Beyond. London, Burnett Books.

Wright M (1996) Justice for Victims and Offenders. Winchester: Waterside Press.

Wright M (2001) Is it time to question the concept of punishment? Paper to fifth international conference 'Positioning Restorative Justice' KU Leuven, 16-19 September 2001. 
Wright M and Galaway B (eds) (1989) Mediation and Criminal Justice: Victims, Offenders and Community. London: Sage

Young R (2002) Testing the limits of Restorative Justice: The Case of Corporate Victims. In: Hoyle $\mathrm{C}$ and Young R (eds) New visions of Crime Victims. Oxford: Hart, pp. 133-172 Zehr H (2002) The Little Book of Restorative Justice. Intercourse: Good Books.

Zehr H (2005) Changing Lenses: A New Focus for Crime and Justice, $3^{\text {rd }}$ ed. Scottdale: Herald Press.

\section{Legal statutes and policy documents}

International

COE Recommendation No. R (99) 19 concerning mediation in penal matters.

EU Directive 2012/29/EU establishing minimum standards on the rights, support and protection of victims of crime (Victims' Directive).

UN Declaration of Basic Principles of Justice for Victims of Crime and Abuse of Power 1985.

UN Basic principles on the use of restorative justice programmes in criminal matters 2002.

\section{England and Wales}

Crown Prosecution Service (CPS) RJ Legal Guidance

HMIC, HMI Probation, HMI Prisons and the HMCPSI, Facing Up To Offending: Use of restorative justice in the criminal justice system 2012.

Home Office, No more excuses White Paper 1997. London: Home Office.

Home Office, The way ahead 2001. London: Home Office.

Home Office, Justice for All White Paper 2002. London: Home Office.

Home Office, Confident Communities in a Secure Britain Strategic plan 2008. London: Home Office.

Home Office, Transforming Rehabilitation: a summary of evidence on reducing reoffending 2013

Ministry of Justice, Restorative Justice Action Plan for the Criminal Justice System in England and Wales 2012.

Ministry of Justice, Restorative Justice Action Plan for the Criminal Justice System in England and Wales 2013.

Ministry of Justice, 'One year on' Progress Report Against the 2013 Restorative Justice Action Plan England and Wales.

Ministry of Justice, Restorative Justice Action Plan for the Criminal Justice System in England and Wales 2014.

Ministry of Justice, Crime and Disorder Act 1998 England and Wales.

Ministry of Justice, Criminal Justice Act 2003 England and Wales.

Ministry of Justice, Criminal Justice \& Immigration Act 2008 England and Wales. 
Ministry of Justice, Breaking the Cycle: Effective Punishment, Rehabilitation and Sentencing of Offenders 2010.

Ministry of Justice, Crime and Courts Act 2013 England and Wales.

Ministry of Justice, Offender Rehabilitation Act 2014 England and Wales.

Ministry of Justice, Code of Practice for Victims of Crime October 2015 England and Wales (Victims' Code).

Restorative Justice Council UK, Best Practice Guidance for Restorative Practice 2011.

Word count: 8841 